\title{
The Effect of Promotion Strategy in the Jordanian Islamic Banks on a Number of Customers
}

\author{
Bader Mustafa Al-Sharif ${ }^{1}$, Amjad Qwader ${ }^{1} \&$ Zaher Abdel Fattah Al-Slehat $^{1}$ \\ ${ }^{1}$ Faculty of Business, Tafila Technical University, At-Tafila, Jordan \\ Correspondence: Bader Mustafa Al-Sharif, Faculty of Business, Tafila Technical University, AT-Tafila, P.O. Box \\ 179, Tafila, 66110, Jordan. E-mail: bader.alsharif99@ gmail.com
}

Received: November 14, 2016

Accepted: December 7, 2016

Online Published: January 10, 2017

doi:10.5539/ijef.v9n2p81

URL: http://dx.doi.org/10.5539/ijef.v9n2p81

\begin{abstract}
This study aimed at recognizing the effect of promotion strategy in the Jordanian Islamic banks on a number of customers. To accomplish the objective of this study, the researcher designed a questionnaire composed of three parts. The first part designed to collect data about the sample, while the second part was designed to collect information about the attitude to deal with Islamic banks. The questionnaire was distributed for a sample of 100 dealers with Islamic banks. The researcher recovered $95 \%$ of the distributed questionnaires. The collected questionnaires were entered to statistical software (SPSS) and analyzed. The results showed that the advertisement is the most important field in promotion that should be concerned by banks to increase its customers. The study concluded that the marketing strategy in Islamic banks is practiced randomly and not concentrated on that Muslims prefer the deal with Islamic banks.
\end{abstract}

Keywords: promotion strategy, Islamic banks

\section{Introduction}

Promotion is considered as one of the means used in order to spread and to increase the market share of the organization by increasing its competition against similar organizations in the market, as well as it is considered as the only means by which the product offers the advantages of the goods provided to final consumer.

Promotion became an essential part of the organization's policy, which is the only means used by the organization in light of the intense competition with other organizations. It is also as a means that enables the organization to reach its target consumers in order to create customer's desire, and here it is necessary to develop firm integrated promotional strategies that contribute to achieving the organization's strategic objectives (Assuhn, 1997).

Competition increased in the Islamic banks sector as a result of increasing orientation towards these banks, the existence of Arab Islamic banks at the Jordanian market, which makes it imperative for these banks to improve their promotion strategies with the intensification of the competition, and at the same time the measurement of the conformity of promotion strategies with the provisions of Islamic law which are consistent with the obligations of individual in the Islamic Community.

This study aims at identifying the effect of promotion strategy in the Jordanian Islamic banks on a number of customers, and how these strategies work on documenting the adherence of these banks to the provisions of Islamic Sharia in their work.

\section{Theoretical Framework}

\subsection{Defining Promotion Strategy}

Promotion is a marketing effort involves a persuasive communication regarding a product or service (Armstrong \& Kotler, 1996).

Promotion is used to inform and remind the customer and to influence its feelings, behavior and beliefs towards the promoted product or service (Stanton, 1997).

Promotion is an integrated communication system based on the delivery of information about the product or service in a persuasive manner to targeted customers in order to make the individuals accept the product or the promoted service (Kincaid, 2003). 


\subsection{Promotion Tools}

1) Advertisement: it is a non-personal communication process to promote products and services such as television, newspapers, and radio for a fee in order to influence the behavior of the people to deal with the banks (Assuhn, 1997).

2) Personal selling: it is a personal communication process aimed at promoting a product or a service; this method of promotion requires a high level of skills, training and the ability to supply and persuasion and the good appearance of the salesman (McCarthy \& Perreault, 2004).

3) Sales promotion: this involves any marketing or non-marketing activity which is used at a specific time to increase the demand for goods and services, such as price discounts and free subscriptions (Abu, 1996).

4) Publicity: this involves any news published about a product or service through the media (television, newspapers, etc. ...) by official authorities. This is a free of charge service such as the raising awareness of the harmful effects of smoking on television by the Ministry of Health (Fzaz, 2014).

5) Public Relations: this process involves the employment of media to build a good image of the bank and the pursuit of satisfaction among the target customers, also through the bank's support of the social, sports, environmental and health activities in the community (Edlayme, 2005).

\subsection{The Importance of Promotion}

\subsubsection{As for the Customers of the Banks}

1) Promotion makes customers know the benefits of banks and the specifications, prices, locations, and times of the products or services provided to them. Promotion provides an environment of entertainment among customers through the sights and poignant expressions accompanying the advertisement process (Alaq \& Rbaba'a, 1998).

2) Promotion reminds customers of their desires and needs through several means including publicity and advertisement (Rachman, 1988).

\subsubsection{As for the Marketing Staff}

1) The increment of the sales size through the interaction of sales staff, distributors and various means of sales promotion (Mualla, 1996).

2) Overcoming the problem of low sales size which usually occurs during Slump in sales stage through promotion (Hurb, 1999).

3) Overcoming the far distance between the bank and customers using the Internet to provide services and products. Promotion increases competition among banks in order to increase demand for sales and services in spite of similar quality and prices (Alaq, Bashir, Abdali, \& Ghalib, 1999).

\section{Literature Review}

Otoum, F.,This study aimed at identifying the impact of banking promotion on the increment of savings accounts at banks operating in Jordan and to determine the best means of promotion. This study has used descriptive analytical approach using a questionnaire distributed to 506 employees working at banks where 357 questionnaires were retrieved. SPSS software was used to perform statistical tests needed to find out the significance between variables. The results of the study showed that advertisements have a significant impact on the increment of savings accounts in banks, followed by public relations through offering prizes to the owners of savings accounts at banks operating in Jordan (Otoum, 2010).

Marji, A., This study aimed at identifying the impact of the use of Internet and cell phone in the promotion by the banks operating in Jordan on the market share of banks. The study has used descriptive analytical approach using a questionnaire distributed to 120 employees working in banks. 100 was questionnaires were retrieved, and then percentages, means, standard deviations were analyzed in order to describe the sample, and statistical tests were used to identify the significance between variables. The results of the study showed that public relations have a significant impact on the increment of market share, and that the e-promotion does not require significant financial resources, despite the scarcity of e-promotion skilled staff, and that $87 \%$ believe that electronic advertisements increase the competitiveness of the bank, and $64 \%$ of respondents emphasized that e-promotion is credible (Marji, 2008).

Edhmour and Shraideh, The study aimed to identify the impact of promotional mix elements (advertisement, publicity and public relations, personal selling, and means of sales promotion) on the Jordanian consumer decisions to use cell phone service .In order to achieve the objectives of the study and to test its hypotheses, a 
questionnaire was designed and distributed to a simple sample of (600) respondents from the study population (494) questionnaires were retrieved with a retrieving percentage of $(82.33 \%)$. The study has used descriptive and analytical approach, and then the percentages, means, standard deviations were analyzed to describe the sample, and statistical tests were used to identify the significance between variables. The study found that a strong impact of promotional mix elements on the Jordanian consumer decisions to use cell phone service (Edhmour \& Shraideh, 2008).

Grankvist, Kollberg, and Person., The study aimed to get a clear understanding of the promotional strategies in the international retail banking in Estonia. Descriptive approach was used. The study showed that personal selling is the most important promotional tool in the retail banking followed by advertisements. Also, the results showed that a strong brand attracts customers, and the study found that market segmentation is essential for the success of the promotion process (Grankvist, Kollberg, \& Person, 2004).

Pitt, Berthon, and Waston., This study aimed at providing a theoretical framework to identify the impact of "the world wide web as an advertising medium descriptive analytical approach was used. The study found a model that consists of six stages, where the model has addressed the problem of recipients of advertising message on the World Wide Web through two groups; one group is interested in the advertising organization and the other group is not interested in the advertising organization. This study has demonstrated that the organization attractiveness (as an advertising tool) for clients depends on the number of members interested in the advertising organization (Pitt, Berthon, \& Waston, 1996).

\section{Methodology}

Islamic banks are characterized by private nature as their principles are derived from Islamic law. The public has a desire to deal with Islamic banks, but because there are some misconceptions about the Islamic transactions, a group of customers are turning to deal with commercial banks; hence the problem of the study is to identify the impact of promotion in the Islamic banks to attract customers.

The study of the impact of promotion strategy on the number of customers of Islamic banks in Jordan is a good outset. In order to enable Islamic banks to increase the bank's ability to compete and spread and then to achieve financial and economic requirements, the study provides information on the level of promotion in Islamic banks and then straightening the bank's path to improve the level of promotion for subsequent periods of time.

Based on this context, the following hypotheses are proposed:

Ho1: There is no statistically significant impact at the level of significance $(\alpha \leq 0.05)$ for the promotion strategy followed by the Jordan Islamic banks (advertisement) on the number of customers of the Islamic banks.

Ho2: There is no statistically significant impact at the level of significance $(\alpha \leq 0.05)$ for the promotion strategy followed by the Jordan Islamic banks (personal selling) on the number of customers of the Islamic banks.

Ho3: There is no statistically significant impact at the level of significance $(\alpha \leq 0.05)$ for the promotion strategy followed by the Jordan Islamic banks (sales promotion) on the number of customers of the Islamic banks.

Ho4: There is no statistically significant impact at the level of significance $(\alpha \leq 0.05)$ for the promotion strategy followed by the Jordan Islamic banks (publicity) on the number of customers of the Islamic banks.

Ho5: There is no statistically significant impact at the level of significance $(\alpha \leq 0.05)$ for the promotion strategy followed by the Jordan Islamic banks (Public relations) on the number of customers of the Islamic banks.

\subsection{Scope of the Study}

The study population consisted of the customers of Islamic banks and due to the difficulty of access to all members of population, the researcher distributed (100) questionnaires on the employees working at Islamic banks, and retrieved (95) with retrieving percentage of $95 \%$. The researcher has entered these questionnaires on a computer in preparation for analysis.

\subsection{The Study Tool}

The study tool consisted of three parts, and the parts were designed as follows:

Part I: this part is dedicated for gathering data of the demographic characteristics of the study sample, which consisted of the following questions:

Gender: This includes (male/female) choice.

Age: The age distribution included 5 categories.

Academic qualifications: The academic qualifications included (high school and less/ diploma/bachelor's 
degree/MA/PhD).

Part II: This part consisted of the independent variable in the study which is (the component of promotion strategy) as this variable was measured using 5-point Likert scale which included:

Advertisement: measured through three statements.

Personal selling: measured through three statements.

Sales promotion: measured through three statements.

Publicity: measured through three statements.

Public Relations: measured through three statements.

Part III: This part included statements relating to the measurement of demand for Islamic banks and 5-point Likert scale has been used for data collection on this part, where this part included the following fields:

The demand for deposit in Islamic banks: it has included three statements.

Commitment to the religious dimension: measured through three statements.

Advantage of Islamic banks over other banks: measured through three statements.

\subsection{Multivariate Analysis - Probit Model}

In order to access the results of the study, the researcher has used the following statistical methods:

Descriptive statistics: the researcher used the frequencies and percentages in order to identify the personal characteristics of the individuals of the sample, while he used means and standard deviations in order to identify the trends of the sample in the study variables.

Statistical inference: The researcher has used simple and multiple regressions for the purpose of measuring the impact of the components of promotion strategy on the demand for Islamic banking and thus test of hypotheses.

\subsection{Validity \& Reliability of Study Tool}

The study tool (questionnaire) was subjected to Validity and Reliability tests in order to ensure the achievement of the objectives of the study as Cronbach's Alpha was used in order to verify the reliability of the current study. The results in Table (1) show reliability in the respondents' responses, because the standard value of Cronbach's Alpha is more than 60\%, which is the accepted percentage in management research (Sekaran, 2008).

Table.1. Reliability test of the results of the study tool (Cronbach's alpha)

\begin{tabular}{lc}
\hline Field & Cronbach's alpha \\
\hline Components of promotion strategy & 0.931 \\
Advertisement & 0.933 \\
Personal selling & 0.853 \\
Sales promotion & 0.881 \\
Publicity & 0.943 \\
Public relations & 0.865 \\
The demand for deposit in Islamic banks & 0.842 \\
Commitment to the religious dimension & 0.921 \\
Advantage of Islamic banks over other banks & 0.897 \\
Demand for Islamic banks & 0.921 \\
The tool as a whole & 0.958 \\
\hline
\end{tabular}

Source: Authors.

\section{Analysis}

\subsection{Sample Attitudes towards the Promotion Strategy of Islamic Banking}

It is noted from the results that sample attitudes towards the promotion strategy of Islamic banking was average, where "advertisement "was rated "very good" where the mean was 3.7 and the standard deviation was 0.59 , and the consent of the statements of "advertisement" was average.

State the results showed a decline in personal selling as compared to advertisement in Islamic banks, where the mean was 3.4 as compared to 3.7 for advertisement, and this refers to the decline in personal selling operations in Islamic banks.

Evaluation of sales promotion, publicity and public relations was average where the mean of each of them was 
3.4, 3.3 and 3.4 which is an average value and the answer all the statements of promotion, publicity and public relations was average.

Table 2. Means, standard deviations for the sample's evaluation of promotion strategy in the Islamic banks

\begin{tabular}{lll}
\hline Statement & Mean & standard deviation \\
\hline Advertisement & 3.80 & 0.61 \\
Islamic banks offer their advertisements that commensurate with the nature of their work & 3.70 & 0.51 \\
Islamic bank advertisements Promote Islamic orientation of the bank & 3.60 & 0.81 \\
Advertisement helps in determining the choice of Islamic banks in preference to commercial ones & 3.70 & 0.59 \\
Average & 3.50 & 0.63 \\
Personal selling & 3.40 & 0.52 \\
Employees working in the Islamic bank give a clearer conceive of Islamic banking transactions & 0.41 \\
Employees working in the Islamic bank clarifies the advantages of Islamic banks over the commercial ones & 0.42 \\
Employees working in the Islamic bank comprehensiveness of service at the Islamic bank & 3.40 \\
Average & 3.40 \\
Sales promotion & 3.50 & 0.32 \\
Islamic banks encourage customers to deal with them & 3.40 \\
The bank contributes to improve its image & 3.30 \\
The Bank provides an image of its activities and transactions & 3.40 \\
Average & & 0.51 \\
Publicity & 3.40 \\
Publicity provided by the bank envisages the promotion strategies & 3.20 \\
Publicity contributes to explain the Islamic banking strategies and transactions & 0.33 \\
Bank works to embed positive aspects of the application of Sharia in its advertisements & 3.20 \\
Average & 3.30 \\
Public relations & & 0.41 \\
Public Relations spread the application of Sharia & 0.32 \\
public relations spread the advantage of Islamic banks over other banks & 0.42 \\
Public relations contribute to improving the image of Islamic banks & 0.39 \\
Average & 3.50
\end{tabular}

Source: Authors.

\subsection{Sample's Attitudes towards the Demand for Islamic Banks}

The evaluation of the demand for deposit in Islamic banks, the commitment to the religious dimension and showing the advantage of Islamic bank over other banks was average where the mean was 3.4, 3.4 and 3.3 respectively. The results showed that the answer to all statements in the areas of demand for deposit in Islamic banks, commitment to the religious dimension and showing the advantage of the bank over other banks was average.

Table 3. Means, standard deviations to evaluate the demand for Islamic banking

\begin{tabular}{llc}
\hline Statement & Mean & standard deviation \\
\hline The demand for deposit in Islamic banks & 3.50 & 0.31 \\
The bank attract customers to deposit in Islamic banks & 3.40 & 0.33 \\
The bank contributes to provide advantages for Innovation in Islamic banks & 3.30 & 0.33 \\
Bank works to explain the deposit transactions in accordance with Islamic Sharia & 3.40 & 0.33 \\
Average & 3.40 & 0.12 \\
Commitment to the religious dimension & 3.40 & 0.33 \\
Islamic bank complies with all Islamic instruction in all banking transactions & 3.30 & 0.34 \\
Bank refuses to perform transactions conflicting with Islamic law & 3.40 & 0.31 \\
The bank takes into account the facilities provided to its customers & 3.40 & 0.41 \\
Average & 3.30 \\
Showing the advantage of the bank over other banks & 3.30 \\
Strategic plan of the bank highlight the positive aspects of Islamic Bank & 3.30 & 0.42 \\
The Bank shows its advantages over for commercial banks & 0.46 \\
The Bank offers its advantages according to the requirements of Islamic law & 0.39 \\
Average & \\
\hline
\end{tabular}

Source: Authors. 


\section{Appropriate Model Test}

Ho1: There is no statistically significant impact at the level of significance $(\alpha \leq 0.05)$ for the promotion strategy followed by the Jordan Islamic banks (advertisement) on the number of customers of the Islamic banks.

Table 4. Regression and t-test of the effect of advertisement on demand for Islamic bank

\begin{tabular}{lccc}
\hline $\mathrm{R}$ & $\mathrm{R} 2$ & Calculated $\mathrm{t}$ value & Significance \\
\hline 0.582 & 0.339 & 11.554 & 0.001 \\
\hline
\end{tabular}

Source: Authors.

The results showed that advertisements contribute to $33.9 \%$ of the demand for Islamic banks. The results showed the presence of statistically significant effect for advertising on demand for Islamic banks as the value of $t$ was (11.554) and the significance level was 0.001 , which is less than the level of significance $(\alpha \leq 0.05)$.

Ho2: There is no statistically significant impact at the level of significance $(\alpha \leq 0.05)$ for the promotion strategy followed by the Jordan Islamic banks (Personal selling) on the number of customers of the Islamic banks.

Table 5. Regression and t-test of the effect of personal selling on demand for Islamic bank

\begin{tabular}{lccc}
\hline $\mathrm{R}$ & $\mathrm{R} 2$ & Calculated $\mathrm{t}$ value & Significance \\
\hline 0.655 & 0.429 & 13.984 & 0.001 \\
\hline
\end{tabular}

Source: Authors.

The results showed that Personal selling contribute to $42.9 \%$ of the demand for Islamic banks. The results showed the presence of statistically significant effect for Personal selling on demand for Islamic banks as the value of $\mathrm{t}$ was (13.984) and the significance level was 0.001 , which is less than the level of significance $(\alpha \leq 0.05)$.

Ho3: There is no statistically significant impact at the level of significance $(\alpha \leq 0.05)$ for the promotion strategy followed by the Jordan Islamic banks (Sales promotion) on the number of customers of the Islamic banks.

Table 6. Regression and t-test of the effect of Sales promotion on demand for Islamic bank

\begin{tabular}{lccc}
\hline $\mathrm{R}$ & $\mathrm{R} 2$ & Calculated t value & Significance \\
\hline 0.593 & 0.352 & 11.871 & 0.001 \\
\hline
\end{tabular}

Source: Authors.

The results showed that Sales promotion contribute to $35.2 \%$ of the demand for Islamic banks. The results showed the presence of statistically significant effect for Sales promotion on demand for Islamic banks as the value of $\mathrm{t}$ was (11.871) and the significance level was 0.001 , which is less than the level of significance $(\alpha \leq 0.05)$.

Ho4: There is no statistically significant impact at the level of significance $(\alpha \leq 0.05)$ for the promotion strategy followed by the Jordan Islamic banks (Publicity) on the number of customers of the Islamic banks.

Table 7. Regression and t-test of the effect of publicity on demand for Islamic bank

\begin{tabular}{lccc}
\hline $\mathrm{R}$ & $\mathrm{R} 2$ & Calculated $\mathrm{t}$ value & Significance \\
\hline 0.727 & 0.529 & 17.073 & 0.001 \\
\hline
\end{tabular}

Source: Authors.

The results showed that Publicity contribute to $52.9 \%$ of the demand for Islamic banks. The results showed the presence of statistically significant effect for Publicity on demand for Islamic banks as the value of $t$ was (17.073) and the significance level was 0.001 , which is less than the level of significance $(\alpha \leq 0.05)$.

Ho5: There is no statistically significant impact at the level of significance $(\alpha \leq 0.05)$ for the promotion strategy followed by the Jordan Islamic banks (Public relations) on the number of customers of the Islamic banks. 
Table 8. Regression and t-test of the effect of public relations on demand for Islamic bank

\begin{tabular}{lccc}
\hline $\mathrm{R}$ & $\mathrm{R} 2$ & Calculated t value & Significance \\
\hline 0.642 & 0.413 & 15.032 & 0.001 \\
\hline
\end{tabular}

Source: Authors.

The results showed that Public relations contribute to $41.3 \%$ of the demand for Islamic banks. The results showed the presence of statistically significant effect for Public relations on demand for Islamic banks as the value of $t$ was (15.032) and the significance level was 0.001 , which is less than the level of significance $(\alpha \leq 0.05)$.

\section{Conclusions and Recommendations}

\subsection{Conclusions}

The current study found the following results:

1) There are deficiencies in Islamic banks marketing strategies and the reason is that these strategies have not been able to attract a large segment of the Muslims to deal with Islamic banks.

2) The components of promotion strategy in the field of advertising, publicity and the field of personal selling, public relations are still immature and the reason is the absence of clear strategies targeting the largest segment of the customers or who are interested in dealing with Islamic banks.

3) The results showed that advertising has the greatest impact on the demand for deposit in Islamic banks.

4) The effect of the other items on the demand for deposit in Islamic banks was average.

\subsection{Recommendations}

Through previous conclusions, we can formulate a set of recommendations as follows:

1) Setting clear policies and strategies with specific targets in Islamic banks and which target a different segments of society.

2) The development of the banking sector to meet the required expectations of these banks and meet the needs of the community.

3) Banks shall avoid circumvention of Islamic law in order to make a profit in order to build a stronger trust with the Muslim.

4) Expand the access to promotion strategies to reach a broad category of citizens who desire to deal with Islamic banks.

\section{References}

Abu, Q., \& Abdul, S. (1996). Lectures in the Declaration Engineering. Alexandria, Egypt: Dar Aljamay'a for Printing and Publishing.

Alaq, B., \& Rbaba'a, A. M. (1998). Promotion and advertising. Integrated Approach, Dar scientific Yazouri, Amman, Jordan.

Alaq, B., Abdali, Q., \& Ghalib, S. (1999). The marketing strategy. Dar Zahran for Publishing and Distribution, Amman, Jordan

Armstrong, G., \& Kotler, P. (1996). Principles of Marketing. Prentice Hall.

Asshun, M. F. (1997). Advertising. Alexandria, Egypt: Dar Aljamay'a for Printing and Publishing.

Edhmour, H. H., \& Shraideh, M. T. (2008). The impact of promotional mix elements of the Jordanian consumer in the use of cellular phone service decisions. Jordanian Business Management Journal, University of Jordan, Amman, Jordan.

Edlayme, A. R. M. (2005). The public relations in the application. Amman, Jordan: Dar Greer for Publishing and Distribution.

Fzaz, K. (2014). The impact of e-marketing on promotion mix in the economic institution. Unpublished Master Thesis, University of Mohamed KHIDER-Biskra, Algeria.

Grankvist, A., Kollberg, C., \& Person, A. (2004). Promotion Strategies for Banking Services. Retrieved from http://www.smartbize. com/article/view440

Hurb, B. H. (1999). Principles of Marketing. Warraq Foundation, Amman, Jordan. 
Kincaid, M., Jr. (2003). Promotion, Product, Service and Ideas (6th ed.). Columbus, Hoi, Bell 7, Howell Co.

Lovelock, C., \& Wirtz, J. (2004). Service Marketing (4th ed., pp. 37-38). Pearson, UK.

Marji, A. M. (2008). The impact of electronic promotion market share in the operating banks in Jordan. Unpublished Master Thesis, Al al-Bayt University, Mafraq, Jordan.

McCarthy, J., \& W. D. Perreault, Jr. (2013). Basic Marketing (5th ed., pp. 37-38). Irwin.

Mualla, N. (1996). The scientific assets of commercial promotion and advertising. The University of Jordan, Jordan.

Otoum, F. R. (2010). The impact of the banking promotion to increase savings accounts at banks operating in Jordan. Unpublished Master Thesis, Yarmouk University, Irbid, Jordan.

Pitt, L., Berthon, P., \& Waston, R. (1996). The World Wide Web as an Advertising Medium: Toward an Understanding of Conversion Efficiency. Journal of Advertising Research, 43-54.

Rachman, D. J. (1988). The Marketing Today (2nd ed.). Rinehart \& Winston, Inc.

Sekaran, U. (2008). Research Methods for Business: A Skill Building Approach. New York: John Wiley and Sons.

Stanton, W. (1997). Fundamental of Marketing (6th ed.). McGraw-Hill, Co.

\section{Copyrights}

Copyright for this article is retained by the author(s), with first publication rights granted to the journal.

This is an open-access article distributed under the terms and conditions of the Creative Commons Attribution license (http://creativecommons.org/licenses/by/4.0/). 